\title{
Islet Cell Antibodies and Diabetes Mellitus in Pima Indians
}

\author{
W. C. Knowler ${ }^{1}$, P.H. Bennett ${ }^{1}$, G. F. Bottazzo ${ }^{2}$, and Deborah Doniach ${ }^{2}$ \\ ${ }^{1}$ Southwestern Field Studies Section, Epidemiology and Field Studies Branch, National Institute of Arthritis, Metabolism, and Digestive \\ Diseases, Phoenix, Arizona, USA, and 2Department of Immunology, Middlesex Hospital Medical School, London, England
}

\begin{abstract}
Summary. Pancreatic islet cell antibodies and 12 other autoantibodies were measured at the time of diabetes diagnosis in 46 Pima Indians, aged 17-47 years, and in 46 age-sex matched non-diabetic controls. Islet cell antibodies were found in only two diabetics, aged 20 and 25, compared with none of 46 controls. Neither of the subjects with islet cell antibodies had other autoantibodies. At least one type of autoantibody was found in $14(30 \%)$ of the diabetics and in 14 controls, but none was significantly associated with diabetes. This study indicates that diabetes in the Pima Indians, even those with an onset below 25 years of age, is almost entirely of type II, in that the disease is not associated with islet cell antibodies, ketoacidosis, or insulin dependence.
\end{abstract}

Key words: American Indians, autoimmunity, diabetes mellitus, islet cell antibodies.

In previous studies on Caucasian populations, isletcell antibodies (ICA) have been found in about $80 \%$ of juvenile insulin-dependent diabetics at the time of diagnosis, but tend to disappear in time, with prevalence rates falling to about $45 \%$ at one year and $25 \%$ at two years after diagnosis [1]. ICA have been shown to react with all four types of islet cells [2], yet they are serological markers for Type I diabetes in which only the insulin-producing beta-cells are destroyed. This makes their direct pathogenetic role uncertain at the present time. All the milder forms of diabetes which can be controlled with diet and oral hypoglycaemic agents (Type II) are unassociated with ICA at any stage of the disease. More recently [3] Type I diabetes has been further subdivided into Type IA which affects mainly children with a slight excess of males, showing seasonal variations and early disappearance of ICA, where the lesion is thought to result from virus infections, and Type IB which affects mainly women, occurs at any age, shows a tendency to persistence of ICA and is thought to represent a 'primary' autoimmune form of the disease $[4,5]$. Persistence of ICA is associated with thyroid and gastric autoimmunity and with HLA type B8 and identifies this small subgroup with a polyendocrine type of serology $[6,7,8]$. In these patients ICA may be found several years before the onset of diabetes and can predict future insulin dependence when the onset is less acute than in the usual juvenile case $[6,8]$.

The Pima Indians of Arizona, USA, have the world's hightest reported incidence of diabetes [9]. The peak incidence is in early adulthood. Pima diabetics are generally nonketotic and in this sense are not insulin dependent, but often require insulin to control hyperglycaemia. The Pimas are a relatively homogeneous population genetically [10], and their diabetes may be predominantly of one type. To characterize diabetes further in the Pimas, we have determined the prevalence of ICA, as well as of antibodies to glucagon and somatostatin producing cells, thyroid, stomach, and adrenal tissue; rheumatoid factor; and antinuclear, smooth muscle, and mitochondrial antibodies. Determinations were made in 46 Pimas with diabetes of recent onset, and in 46 age and sex matched non-diabetic controls.

\section{Methods}

\section{Subjects}

Subjects were selected from a long-term followup study of diabetes in Pima Indians living on the Gila River Community of Arizona, USA [11]. This study involved biennial examinations, including history, physical examination, and plasma glucose [12] 
Table 1. Characteristics of the 46 recent onset diabetic subjects

\begin{tabular}{llcl}
\hline $\begin{array}{l}\text { Age } \\
\text { group (years) }\end{array}$ & Male & Female & $\begin{array}{l}\text { Subsequently } \\
\text { insulin treated }\end{array}$ \\
\hline $17-25$ & 6 & 4 & $60 \%$ \\
$26-35$ & 4 & 8 & $58 \%$ \\
$36-47$ & 8 & 16 & $29 \%$ \\
\hline
\end{tabular}

two hours after a $75 \mathrm{~g}$ oral carbohydrate load. Forty-six subjects were studied at the first examination at which a diabetes diagnosis was made, to maximize the chances of finding ICA (Table 1). Diagnosis was based on abnormal post load glucose concentration $\geq 200 \mathrm{mg} / \mathrm{dl}$ (mean \pm SEM: $318 \pm 16 \mathrm{mg} / \mathrm{dl}$ ). Fourteen $(30 \%)$ subjects complained of classic symptoms of diabetes (such as polyuria, polydipsia, or weight loss) for periods of at most a few months preceding diagnosis. None had been previously diagnosed or treated for diabetes. Each diagnosis was confirmed by further glucose tolerance testing. Subjects were of at least half Pima heritage and aged seventeen through forty-seven years. All subjects had normal glucose tolerance at earlier testing (mean two hour plasma glucose, $124 \pm 3 \mathrm{mg} / \mathrm{dl}$ ). The median interval between the normal test and diagnosis was 2.3 years (mean 2.8 years, range 1.7 to 10 years, $75 \%$ were less than 3 years). The patients have been reviewed for an average of six years since diagnosis, during which time many have progressed to insulin treatment (Table 1).

Sera collected and frozen at the time of diagnosis were used for the autoantibody tests. In the diabetic subjects aged twenty-five years or less at diagnosis, additional sera were tested from all examinations preceding and following diagnosis.

Paired control subjects, matched for age and sex, were also studied. They had normal two hour plasma glucose concentrations (104 $\pm 3 \mathrm{mg} / \mathrm{dl}$ ) which persisted for at least four years of followup.

\section{Antibodies}

Antibodies to islet cells, glucagon-producing (alpha) cells, and somatostatin-producing (delta) cells were detected by immunoflourescence as previously described [13, 14]. Thyroid, gastric parietal cell, intrinsic factor, adrenal, antinuclear, smooth muscle, and mitochondrial antibodies and rheumatoid factor were determined by standard methods [15].

\section{Results}

\section{Antibodies at Diagnosis}

ICA were found in no control subjects but in two diabetics, a 20 year old man and a 25 year old woman. The antibodies were of low titre (detected only in undiluted serum) and were not associated with other autoantibodies. One subject has been insulin treated subsequently, but takes insulin only intermittently despite persistent hyperglycaemia. The other received insulin during a pregnancy, but otherwise has been treated with oral hypoglycaemic agents. Neither has developed ketoacidosis. Thus, neither can be considered insulin dependent, even though insulin treated.
Glucagon cell antibodies, at a titre of $1 / 32$, were found only in one 46 year old male recent onset diabetic, and were also present in his previous and subsequent sera. The three subjects having ICA or glucagon cell antibodies were of full Pima heritage. No ICA or glucagon cell antibodies were found in non-diabetics, and no somatostatin cell antibodies were found in either group. The prevalence rates of all autoantibodies studied are shown in Table 2. At least one type of autoantibody was seen in $30 \%$ of cases and in $30 \%$ of controls.

\section{Sequential Antibody Determinations}

Sera were tested from two to four years before and from two to five years after the diagnosis of diabetes in seven of the ten subjects aged 25 years or less, including the two subjects with islet cell antibodies at diagnosis. Islet cell antibodies were temporary in these two subjects; they were not found in sera taken four years before, or two months, three years, or five years after the diagnosis. ICA were not found in any of the other pre- or post-diagnosis sera.

Pre- and post-diagnosis sera were also examined in the subject with glucagon cell antibodies. Glucagon cell antibodies were found persistently in titres between $1 / 8$ and $1 / 32$ in all five sera taken from $21 / 2$ years before to three years after the diagnosis of diabetes. Glucagon cell antibodies were not found in any sera from other subjects.

\section{Discussion}

Table 3 compares the prevalence of islet cell antibodies in the present study with two previous studies of insulin-treated subjects in the United Kingdom. Comparisons are hazardous because islet cell antibody prevalence is related to duration of diabetes. Most subjects in the present study had normal glucose tolerance 2 to 3 years prior to diagnosis. Only $30 \%$ had symptoms (of at most a few months' duration) at the time of diagnosis. Thus the duration of diabetes at diagnosis may have been only a few months, at least in the symptomatic patients. Because it is not known, in general, how the onset of symptoms relates to the onset of abnormal glucose tolerance, dating diabetes onset by symptoms is of unknown accuracy. No documentation of normal glucose tolerance prior to diabetes diagnosis was given in the previous British reports, so precise demarcation of diabetes onset was not possible in any of these studies. Thus the Pima prevalence rates for ICA of $4 \%$ in recent onset diabetics or $10 \%$ in Pimas who were subsequently insulin treated are compared with 
Table 2. Autoantibodies in 46 Pima Indian diabetics and 46 age and sex matched non-diabetic controls. None of the case versus control differences was statistically significant at $\alpha=0.05$ by the binomial test for matched pairs [16]

\begin{tabular}{|c|c|c|c|c|}
\hline & \multicolumn{2}{|l|}{ Prevalence } & \multicolumn{2}{|c|}{$\begin{array}{l}\text { Number of pairs discordant } \\
\text { for presence of antibody }\end{array}$} \\
\hline & $\begin{array}{l}\text { Cases } \\
\text { no. }(\%)\end{array}$ & $\begin{array}{l}\text { Controls } \\
\text { no. }(\%)\end{array}$ & $\begin{array}{l}\text { Present in } \\
\text { case only }\end{array}$ & $\begin{array}{l}\text { Present in } \\
\text { control only }\end{array}$ \\
\hline \multicolumn{5}{|l|}{ Pancreas } \\
\hline Islet cell & $2(4 \%)$ & $0(0 \%)$ & 2 & 0 \\
\hline Glucagon cell & $1(2 \%)$ & $0(0 \%)$ & 1 & 0 \\
\hline Somatostatin cell & $0(0 \%)$ & $0(0 \%)$ & 0 & 0 \\
\hline \multicolumn{5}{|l|}{ Thyroid } \\
\hline Thyroglobulin & $3(7 \%)$ & $2(4 \%)$ & 3 & 2 \\
\hline Microsomal & $5(11 \%)$ & $1(2 \%)$ & 5 & 1 \\
\hline \multicolumn{5}{|l|}{ Stomach } \\
\hline Gastric parietal cell & $1(2 \%)$ & $2(4 \%)$ & 1 & 2 \\
\hline Intrinsic factor & $0 \quad(0 \%)$ & $0(0 \%)$ & 0 & 0 \\
\hline Adrenal cytoplasmic & $0(0 \%)$ & $0 \quad(0 \%)$ & 0 & 0 \\
\hline \multicolumn{5}{|l|}{ Rheumatoid factor } \\
\hline Latex agglutination & $5(11 \%)$ & $10(21 \%)$ & 4 & 9 \\
\hline Hemagglutination & $1(2 \%)$ & $5(11 \%)$ & 1 & 5 \\
\hline Antinuclear & $0(0 \%)$ & $2(4 \%)$ & 0 & 2 \\
\hline Smooth muscle & $1(2 \%)$ & $1(2 \%)$ & 1 & 1 \\
\hline Mitochondrial & $0 \quad(0 \%)$ & $0 \quad(0 \%)$ & 0 & 0 \\
\hline At least one of the above & $14(30 \%)$ & $14(30 \%)$ & 11 & 11 \\
\hline
\end{tabular}

Table 3. Islet-cell antibodies in Pima and Caucasian diabetics. The Pima rates (all Pimas or only insulin treated) are significantly different ( $\mathrm{p}<0.05$ by chi-square) from the pooled Caucasian rates at both time periods shown

\begin{tabular}{lccc}
\hline Subjects & $\begin{array}{l}\text { No. } \\
\text { tested }\end{array}$ & $\begin{array}{l}\text { No. } \\
\text { positive }\end{array}$ & Prevalence (\%) \\
\hline $\begin{array}{l}\text { Newly diagnosed Pima } \\
\text { diabetics }\end{array}$ & 46 & 2 & $(4 \%)$ \\
$\begin{array}{l}\text { Newly diagnosed Pima } \\
\text { diabetics-insulin treated }\end{array}$ & 20 & 2 & $(10 \%)$ \\
$\begin{array}{l}\text { Insulin treated Caucasian } \\
\text { diabetics within one month } \\
\text { of diagnosis [1] }\end{array}$ & 191 & 132 & $(69 \%)$ \\
$\begin{array}{l}\text { Insulin treated Caucasian } \\
\text { diabetics within one month } \\
\text { of diagnosis [6] }\end{array}$ & 52 & 34 & $(65 \%)$ \\
$\begin{array}{l}\text { Insulin treated Caucasian } \\
\text { diabetics one to two years } \\
\text { after diagnosis [1] }\end{array}$ & 86 & 28 & $(33 \%)$ \\
$\begin{array}{l}\text { Insulin treated Caucasian } \\
\text { diabetics one to two years } \\
\text { after diagnosis [6] }\end{array}$ & 35 & 14 & $(40 \%)$
\end{tabular}

a Numbers from Caucasian reports are approximate, as read from figures

the Caucasian rates of $69 \%$ or $65 \%$ in those tested within one month of diagnosis or $33 \%$ or $40 \%$ in those tested one to two years after diagnosis. Not only were islet cell antibodies infrequent in recent onset Pima diabetics, but they did not persist beyond the time of diagnosis, in contrast to the findings in some Caucasians with diabetes associated with other organ-specific autoantibodies $[7,8]$. The importance of glucagon cell antibodies is unknown.

None of the autoantibodies studied in this population were significantly associated with diabetes, although a much larger study would be required to show significant case versus control differences in prevalence rates as low as those found. Most autoantibodies were found in frequencies similar to those in Caucasian populations. The high prevalence of rheumatoid factor in Pima Indians has been described previously [17], although its cause and importance are unknown.

These results indicate that very few Pima Indian diabetics belong to the same category as juvenile insulin-dependent Caucasians, despite the young ages of onset and the fact that diabetes in the Pimas is often manifested by severe hyperglycaemia and accompanied by microvascular complications such as retinopathy [18], nephropathy [19], and a greater frequency of coronary artery disease than in the nondiabetic Pima [20]. Thus, diabetes in the Pima Indians could be classified almost entirely as type II $[3,4,5]$, being characterized by absence of islet cell antibodies, ketosis resistance, and lack of insulin dependence.

Acknowledgements. The authors thank the Gila River Indian Community of Arizona, USA, for their cooperation and participation; Mrs. B. Dean, Miss M. O'Kane, Miss M. Shattock, Mrs. M. Barham and Mrs. L. Phillips for their skilled technical assistance; and Dr. G. B. Hutchison for advice. 
This work was supported in part by the Medical Research Council, the British Diabetic Association and the Juvenile Diabetes Foundation (USA).

\section{References}

1. Lendrum, R., Walker, G., Cudworth, A. G., Theophanides, C., Pyke, D. A., Bloom, A., Gamble, D. R.: Islet-cell antibodies in diabetes mellitus. Lancet 1976 II, 1273-1276

2. Bottazzo, G. F., Doniach, D.: Islet cell antibodies (ICA) in diabetes mellitus: evidence of an autoantigen common to all cells in the islet of Langerhans. Ric. Clin. Lab. 8, 29-38 (1978)

3. Bottazzo, G.F., Doniach, D.: Pancreatic autoimmunity and HLA antigens. Lancet 1976 II, 800

4. Cudworth, A. G., Bottazzo, G. F., Doniach, D.: Genetic and immunological factors in Type 1 diabetes. In: Immunological aspects of diabetes mellitus. Irvine, W. J. (Ed.). Teviott Scientific Publications 1979 (In press)

5. Rotter, J. I., Rimoin, D. L.: Heterogeneity in diabetes mellitus update, 1978: evidence for further genetic heterogeneity within juvenile-onset insulin-dependent diabetes mellitus. Diabetes 27, 599-608 (1978)

6. Irvine, W. J., McCallum, C. J., Gray, R. S., Campbell, C. J., Duncan, L. J.P., Farquhar, J. W., Vaughan, H., Morris, P. J: Pancreatic islet-cell antibodies in diabetes mellitus correlated with the duration and type of diabetes, coexistent autoimmune disease, and HLA type. Diabetes 26, 138-147 (1977).

7. Bottazzo, G. F., Mann, J. I., Thorogood, M., Baum, J.D., Doniach, D.: Autoimmunity in juvenile diabetics and their families. Br. Med. J. 1978 II, 165-168.

8. Bottazzo, G. F., Cudworth, A. G., Moul, D. J., Doniach, D., Festenstein, H.: Evidence for a primary autoimmune type of diabetes mellitus. Br. Med. J. 1978 II, 1253-1255

9. Knowler, W. C., Bennett, P. H., Hamman, R. F., Miller, M.: Diabetes incidence and prevalence in Pima Indians - a 19-fold greater incidence than in Rochester, Minnesota. Am. J. Epidemiol. 108, 497-505 (1978)

10. Matson, G. A., Burch, T. A., Polesky, H. F., Swanson, J., Sutton, H. E., Robinson, A.: Distribution of hereditary factors in the blood of Indians of the Gila River, Arizona. Am. J. Phys. Anthropol. 29, 311-337 (1968)
11. Bennett, P. H., Burch, T. A., Miller, M.: Diabetes mellitus in American (Pima) Indians. Lancet 1971 II 125-128

12. Technicon Autoanalyzer Method File N-20. Tarrytown, N. Y.: Technicon Instruments Corp. 1965

13. Bottazzo, G. F., Florin-Christensen, A., Doniach, D.: Islet-cell antibodies in diabetes mellitus with autoimmune polyendocrine deficiencies. Lancet 1974 II, 1279-1283

14. Bottazzo, G. F., Lendrum, R.: Separate autoantibodies to human pancreatic glucagon and somatostatin cells. Lancet 1976 II, 873-876

15. Manual for Autoimmune Serology. Geneva: World Health Organization 1969

16. Armitage, P.: Statistical methods in medical research. p. 127. Oxford: Blackwell Scientific Publications. 1971

17. O'Brien, W. M., Bennett, P. H., Burch, T. A., Bunim, J. J.: A genetic study of rheumatoid arthritis and rheumatoid factor in Blackfeet and Pima Indians. Arthritis Rheum. 10, 163-179 (1967)

18. Dorf, A., Ballintine, E.J., Bennett, P.H., Miller, M.: Retinopathy in Pima Indians: relationships to glucose level, duration of diabetes, age at diagnosis of diabetes and age at examination in a population with a high prevalence of diabetes mellitus. Diabetes 25, 554-560 (1976)

19. Kamenetzky, S. A., Bennett, P. H., Dippe, S. E., Miller, M., LeCompte, P. M.: A clinical and histologic study of diabetic nephropathy in the Pima Indians. Diabetes 23, 61-68 (1974)

20. Ingelfinger, J. A., Bennett, P. H., Liebow, I. M., Miller, M.: Coronary heart disease in the Pima Indians: electrocardiographic findings and post mortem evidence of myocardial infarction in a population with a high prevalence of diabetes mellitus. Diabetes 25, 561-565 (1976)

Received: January 2, 1979,

and in revised form: May 23, 1979

Dr. W. C. Knowler

National Institute of Arthritis,

Metabolism and Digestive Diseases

1440 East Indian School Road

Phoenix, AZ 85014

USA 